UDC $681.518(045)$

DOI: $10.18372 / 1990-5548.56 .12934$

${ }^{1}$ O. A. Sushchenko,

${ }^{2}$ N. D. Novytska,

${ }^{3}$ Y. M. Bezkorovainyi,

${ }^{4}$ V. O. Golitsyn

\title{
ROBUST UAV CONTROL SYSTEM WITH REDUNDANT NONORTHOGONAL MEASURING INSTRUMENT
}

\author{
${ }^{1,2,3,4}$ Educational\&Scientific Institute of Air Navigation, Elctronics and Telecommunications \\ National Aviation University, Kyiv, Ukraine \\ E-mails: ${ }^{1}$ sushoa@ukr.net, ${ }^{2}$ n-m@ukr.net, ${ }^{3}$ yurii.bezkor@gmail.com, ${ }^{4}$ vova.gol@ukr.net
}

\begin{abstract}
The paper deals with synthesis of robust system assigned for operation on unmanned aerial vehicles. A feature of the system lies in using nonorthoginal measuring instrument. Synthesis of the controller was carried out by means of the robust structural synthesis. Such an approach requires development of the mathematical model of a plant. Therefore models of longitudinal and lateral motion of an unmanned aerial vehicle' were obtained. These models take into consideration nonorthogonal redundant measuring system, which includes rate gyroscopes based on microelectromechanical systems technology. Matrices of state, control, observation in the state space were obtained using AeroSim Technology. Results of synthesied system simulation are represented. The obtained results can be useful for moving vehicles of the wide class.
\end{abstract}

Index Terms: Control system; nonorthogonal configuration; rate gyroscope; redundancy; robust controller.

\section{INTRODUCTION AND PROBLEM STATEMENT}

Nowadays development of unmanned aerial vehicles (UAVs) is one of modern trends in aviation. The most important applications of UAVs are photography, aero-surveys and monitoring of environment parameters in regions difficult of access. Functioning of UAVs is implemented in difficult conditions accompanied with parametric and coordinate disturbances. Usage of robust control is one of ways to solve this problem. As a rule, measurement of navigation inertial information on UAVs is carried out by means of accelerometers and gyroscopes manufactured on technologies of microelectro-mechanical systems (MEMS). Such an approach provides low cost, small dimensions and low power consumption of inertial measuring system. It is known that systems of motion control must be reliable and accurate. To improve accuracy of UAV navigation information is possible using structural redundancy of primary navigation measuring instruments based on nonorthogonal orientation of sensitivity axes [1].

There are some approaches to implementation of structural redundancy of measuring instruments. The first approach lies in using of redundant inertial measuring instruments. In this case it is necessary to use the highly productive processor that complicates architecture and raises the price of the navigation systems as a whole. The second approach lies in using of redundant sensors as components of the single measuring instrument. In this case requirements to computational burden and capacity of data transmission channel are greatly less in comparison with the first approach. So, the second approach to using of structural redundancy seems more preferable [2].

There is variety of configurations of nonorthogonal redundant measuring instruments based on MEMS-sensors, for example, represented in [3]. Choice of configuration is defined by the concrete conditions of UAV operation.

The generalised structural scheme of UAV navigation system using structural redundancy is represented in Fig. 1.

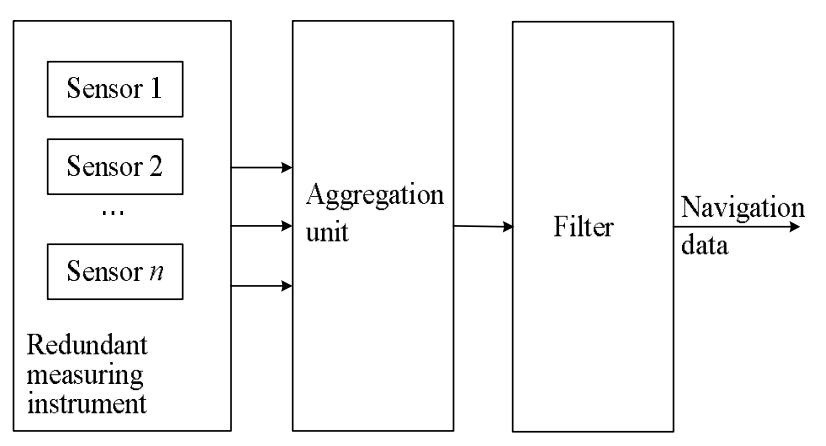

Fig. 1. The structural scheme of the redundant inertial measuring system

Respectively, the structural scheme of the system of UAV motion control can be represented by the scheme shown in Fig. 2. 


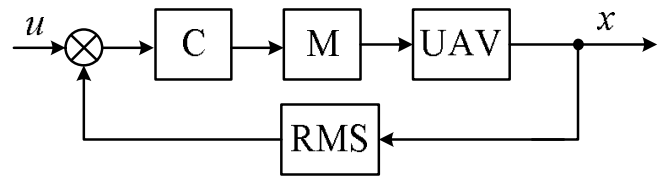

Fig. 2. The structural scheme of the system, which controls UAV motion: $\mathrm{C}$ is the controller; $\mathrm{M}$ is the motor; RMS is redundant measuring instrument

The problem statement lies in solving some interrelated tasks. The first task is choice of nonorthogonal redundant configuration and aggregation algorithm. The main goal of the aggregation algorithm is transformation of data entering from MEMS-sensors into projections of the navigation parameters (accelerations, angular rates) onto the axes of the navigation reference frame. The second task is design of the robust controller based on methods of theory of robust control. The method of the robust structural synthesis $\left(H_{\infty}\right.$-synthesis) can be used in this case.

\section{CHOICE OF NONORTOGONAL CONFIGURATION OF INERTIAL SENSORS}

Different types of nonorthogonal configurations based on MEMS-gyroscopes are represented in [3]. To simplify process of robust system design is convenient to consider nonorthogonal configuration based on single (uniaxial) sensors. It is known that one of the most widespread nonortogonal configurations is based on such geometrical figure as a cone [4]. In this case sensitivity axes of sensors are oriented along a cone's generatrices.

The results of the comparative analysis of accuracy for different nonorthogonal configurations of uniaxial sensors are represented in Table I [5]. This table includes data about values of traces of the correlation matrices of errors for various nonorthogonal redundant configurations in different situations of sensor failures.

TABLE I

RESULTS OF COMPARATIVE ANALYSIS OF NONORTHOGONAL CONFIGURATIONS OF INERTIAL SENSORS

\begin{tabular}{|l|l|l|l|l|}
\hline \multirow{2}{*}{$\mathbf{N}$} & \multirow{2}{*}{ Type of configuration } & \multicolumn{3}{|l|}{ Trace of correlation matrix of errors } \\
\cline { 3 - 5 } & Without faults & 2 faults & 3 faults \\
\hline 1 & 5 sensors along the cone's generatrices & 2.21 & 3.20 & 3.92 \\
\hline 2 & 6 sensors along the cone's generatrices & 1.79 & 2.13 & 4.50 \\
\hline 3 & $\begin{array}{l}\text { 4 sensors along the cone's generatrices } \\
\text { and 1 along the symmetry axis }\end{array}$ & 1.93 & 3.15 & 5.00 \\
\hline 4 & $\begin{array}{l}\text { 5 sensors along the cone's generatrices } \\
\text { and 1 along the symmetry axis }\end{array}$ & 1.70 & 2.18 & 3.35 \\
\hline
\end{tabular}

In accordance with the data given in Table I, the best variant is the fourth one.

The mutual location of axes of the reference frame Oxyz that defines location of the UAV in the inertial space is represented in Fig. 3.

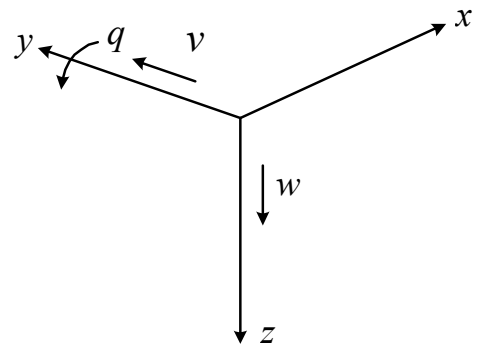

Fig. 3. Oxyz is the body-axis reference frame: $\mathrm{O} z$ is the vertical down-directed axis; $\mathrm{O} x$ is the longitudinal axis; $\mathrm{O} y$ is the lateral axis

Orientation of redundant measuring instrument consisting of 5 sensitive elements (SE) located on a cone's generatrices and 1 sensitive element located along the symmetry axis is shown in Fig. 4.

The following notations are used in Fig. 4: $x y z$ is the navigation reference frame; $l_{1} l_{2} l_{3} l_{4} l_{5} l_{6}$ is the measuring reference frame; angles $\theta, \alpha$ are defined in the following way: $\theta=54^{\circ} 44^{\prime}, \alpha=36^{\circ}$.

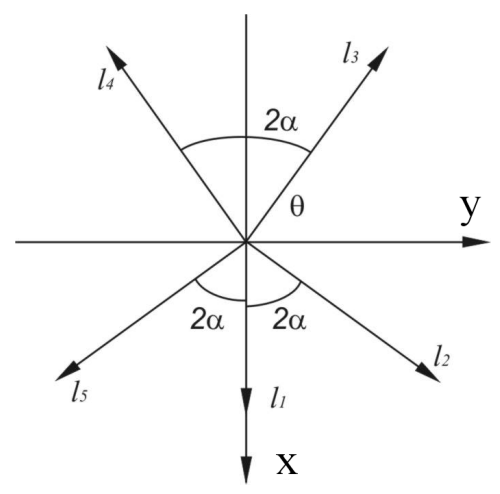

Fig. 4. Orientation of 5 SE on a cone's generatrices and $1 \mathrm{SE}$ along the symmetry axis

Matrix of directional cosines for the above presented nonorthogonal configuration becomes

$$
\mathbf{H}=\left[\begin{array}{ccc}
\sin \theta & -\cos \theta & 0 \\
\cos 2 \alpha \sin \theta & -\cos \theta & \sin 2 \alpha \sin \theta \\
-\cos \alpha \sin \theta & -\cos \theta & \sin \alpha \sin \theta \\
-\cos \alpha \sin \theta & -\cos \theta & -\sin \alpha \sin \theta \\
\cos 2 \alpha \sin \theta & -\cos \theta & -\sin 2 \alpha \sin \theta \\
0 & -1 & 0
\end{array}\right]
$$


The connection between the primary information measured by sensors and navigation information about angular rate can be represented in the following form [4]

$$
\mathbf{l}=\mathbf{H} \boldsymbol{\omega},
$$

where $\left[l_{1} l_{2} \ldots l_{n}\right]^{\mathrm{T}}$ is the vector of projections of the angular rate, measured in the measuring reference frame; $\left[\omega_{x} \omega_{y} \omega_{z}\right]^{\mathrm{T}}$ is the vector of projections of the angular rate in the navigation reference frame; $n$ is quantity of sensors in the measuring instrument. The matrix $\mathbf{H}$ is called the matrix of transformation between navigation reference frame and redundant measuring frame.

Taking into consideration (2), the formula for angular rate determination can be represented in the following form [4]

$$
\boldsymbol{\omega}=\mathbf{H}^{-1} \mathbf{l} .
$$

The expression for the pseudoinverse matrix based on the Moore-Penrose algorithm can be represented in the following form

$$
\mathbf{H}^{-1}=\left(\mathbf{H}^{T} \mathbf{H}\right)^{-1} \mathbf{H}^{T}=\left[\mathbf{H}_{\omega_{x}}^{-1} \mathbf{H}_{\omega_{y}}^{-1} \mathbf{H}_{\omega_{z}}^{-1}\right] .
$$

Expressions (1) - (4) describe the aggregation algorithm for the system of the considered type.

\section{MATHEMATICAL MODEL OF UAV}

The above stated problem can be solved on the example of Aerosonde, which is a small UAV assigned for observation of weather conditions including temperature, atmosphere pressure, humidity and wind above the ocean and remote terrains [6]. The linearized model of Aerosonde as a plant can be represented by the set of equations in the state space

$$
\left\{\begin{array}{l}
\dot{\mathbf{x}}=\mathbf{A x}+\mathbf{B u} \\
\mathbf{y}=\mathbf{C x}+\mathbf{D u}
\end{array} .\right.
$$

Dynamic of the longitudinal motion of Aerosonde can be described by the state vector [6], [7]

$$
\mathbf{x}=[v, w, q, \theta, h, \Omega]^{\mathrm{T}},
$$

where $v, w$ are horizontal and vertical components of the true airspeed; $q$ is the pitch angular rate; $\theta$ is an angle of the pitch; $h$ is the flight altitude; $\Omega$ is an angular rate of the motor (in revolutions per minute). Control of the longitudinal motion is implemented by means of elevator deviations and control of engine thrust. So, the control vector looks like

$$
u=\left[\delta_{e}, \delta_{t h}\right]^{\mathrm{T}},
$$

where $\delta_{e}, \delta_{t h}$ are deviations of elevator and steering wheel for traction control, respectively.

The output vector can be represented in the following form

$$
\mathbf{y}=\left[V_{a}, \alpha, q, \theta, h\right],
$$

where $V_{a}$ is the true airspeed, $\alpha$ is an angle of the attack.

The linearized equations of the longitudinal motion can $b$ described in the following way

$$
\left\{\begin{array}{l}
\dot{v}=Y_{v} v+Y_{w} w+Y_{q} q+Y_{\theta} \theta+Y_{h} h+Y_{\Omega} \Omega+Y_{\delta_{e}} \delta_{e}+Y_{\delta_{t h}} \delta_{t h} ; \\
\dot{w}=Z_{v} v+Z_{w} w+Z_{q} q+Z_{\theta} \theta+Z_{h} h+Z_{\Omega} \Omega+Z_{\delta_{e}} \delta_{e}+Z_{\delta_{t h}} \delta_{t h} ; \\
\dot{q}=M_{v}^{y} v+M_{w}^{y} w+M_{q}^{y} q+M_{\theta}^{y} \theta+M_{h}^{y} h+M_{\Omega}^{y} \Omega+M_{\delta_{e}}^{y} \delta_{e}+M_{\delta_{t h h}}^{y} \delta_{t h} ; \\
\dot{\theta}=H_{\omega_{y}}^{-1} q \\
\dot{h}=\theta+H_{v} v+H_{w} w ; \\
\dot{\Omega}=h+T_{v} v+T_{w} w+T_{\delta_{t h}} \delta_{t h} .
\end{array}\right.
$$

Taking into consideration the expression (6), matrices $\mathbf{A}$ and $\mathbf{B}$ of the state space model (5) can be represented in the following form

$$
\mathbf{A}=\left[\begin{array}{cccccc}
Y_{v} & Y_{w} & Y_{q} & Y_{\theta} & Y_{h} & Y_{\Omega} \\
Z_{v} & Z_{w} & Z_{q} & Z_{\theta} & Z_{h} & Z_{\Omega} \\
M_{v} & M_{w} & M_{q} & M_{\theta} & M_{h} & M_{\Omega} \\
0 & 0 & H_{\omega_{y}}^{-1} & 0 & 0 & 0 \\
H_{v} & H_{w} & 0 & 1 & 0 & 0 \\
T_{v} & T_{w} & 0 & 0 & 1 & 0
\end{array}\right]
$$

$$
\mathbf{B}=\left[\begin{array}{cc}
Y_{\delta_{e}} & Y_{\delta_{t h}} \\
Z_{\delta_{e}} & Z_{\delta_{t h}} \\
M_{y} & M_{y} \\
0 & 0 \\
0 & 0 \\
0 & T_{\delta_{t h}}
\end{array}\right]
$$

Elements of the matrix (7) are components depending on UAV aerodynamics and motor construction. The matrix (8) in the expression (5) is 
represented for the generalized case of two controls [8]. The above given matrices (7) and (8) are matrices of states and observations.

Nowadays synthesis of robust control in many cases is based on the state space models (5). For the above mentioned UAV such matrices can be obtained using AeroSim package of MatLab system [9]. So, matrices of state, control and observation in the numerical form look like

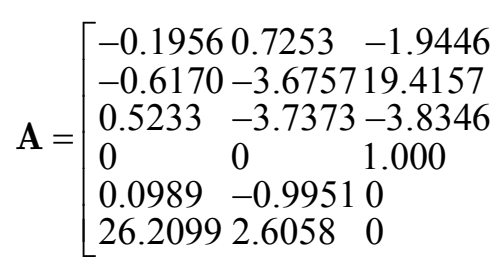

$$
\begin{aligned}
& -9.7757-0.00010 .0099 \\
& -0.97190 .001 \quad 0 \\
& \begin{array}{lll}
0 & 0 & -0.0068 \\
0 & 0 & 0 \\
1 & 0.9998 & 0
\end{array} \\
& 19.99980 \quad 0 \\
& 0 \quad-0.0118-2.0073 \\
& \mathbf{B}=\left[\begin{array}{cc}
0.2901 & 0 \\
-1.6556 & 0 \\
-20.9145 & 0 \\
0 & 0 \\
0 & 0 \\
0 & 299.711
\end{array}\right] \\
& \mathbf{C}=\left[\begin{array}{ccccccc}
0.9951 & 0.09 & 89 & 0 & 0 & 0 & 0 \\
-0.0049 & 0.0498 & 0 & 0 & 0 & 0 \\
0 & 0 & 1 & 0 & 0 & 0 \\
0 & 0 & 0 & 1 & 0 & 0 \\
0 & 0 & 0 & 0 & 1 & 0
\end{array}\right]
\end{aligned}
$$

For the model of the lateral motion the vector of states becomes $\mathbf{x}=[v, p, r, \varphi, \psi]^{\mathrm{T}}$, where $\beta$ is the angle of slide; $p, r$ are angular rates of roll and yaw, $\varphi, \psi$ are angles of roll and yaw [10]. Vector of control is defined as $\mathbf{u}=\left[\delta_{\alpha}, \delta_{r}\right]^{\mathrm{T}}$, where $\delta_{a}, \delta_{r}$ are angles of deviations of ailerons and rudder. The vector of output looks like $y=[\beta, p, r, \varphi, \psi]^{\mathrm{T}}[6],[7]$.
The linearized equations of the lateral motion can be written in the following form

$$
\left\{\begin{array}{l}
\dot{v}=X_{v} v+X_{p} p+X_{r} r+X_{\varphi} \varphi+X_{\delta_{a}} \delta_{a}+X_{\delta_{r}} \delta_{r}, \\
\dot{p}=M_{v}^{x} v+M_{p}^{x} p+M_{r}^{x} r+M_{\varphi}^{x} \varphi+M_{\delta_{a}}^{x} \delta_{a}+M_{\delta_{r}}^{x} \delta_{r}, \\
\dot{r}=M_{v}^{z} v+M_{p}^{z} p+M_{r}^{z} r+M_{\varphi}^{z} \varphi+M_{\delta_{a}}^{z} \delta_{a}+M_{\delta_{r}}^{z} \delta_{r}, \\
\dot{\varphi}=H_{\omega_{x}}^{-1} p \\
\dot{\psi}=H_{\omega_{z}}^{-1} r .
\end{array}\right.
$$

Matrices of the aerodynamic coefficients $\mathbf{A}$ and B look like

$$
\begin{aligned}
\mathbf{A} & =\left[\begin{array}{ccccc}
Y_{v} & Y_{p} & Y_{r} & Y_{\varphi} & Y_{\psi} \\
L_{v} & L_{p} & L_{r} & L_{\varphi} & L_{\psi} \\
N_{v} & N_{p} & N_{r} & N_{\varphi} & N_{\psi} \\
0 & H_{\omega_{x}}^{-1} & 0 & 0 & 0 \\
0 & 0 & H_{\omega_{z}}^{-1} & 0 & 0
\end{array}\right], \\
\mathbf{B} & =\left[\begin{array}{cc}
X_{\delta_{a}} & Y_{\delta_{r}} \\
M_{\delta_{a}}^{x} & L_{\delta_{r}} \\
M_{\delta_{a}}^{z} & M_{\delta_{r}}^{z} \\
0 & 0 \\
0 & 0
\end{array}\right] .
\end{aligned}
$$

The matrix (14) is represented for the generalized case, namely, for two controls [8].

The expressions (6) - (14) are written taking into consideration the reference frame represented in Fig. 1. Such reference frames and notations correspond to foreign technical literature [7], [11]. Here $Y$ means the first derivative of the lateral force by the appropriate parameters; $L$ and $N$ are moments by the roll and yaw.

The numerical matrices of state, control and observation obtained by means of AeroSim Package look like

$$
\mathbf{A}=\left[\begin{array}{ccccc}
-0.5702 & 1.9786 & -19.9017 & 9.7757 & 0 \\
-3.3984 & -16.7803 & 8.0757 & 0 & 0 \\
0.5434 & -2.1680 & -0.8281 & 0 & 0 \\
0 & 1 & 1 & 0.0994 & 0 \\
0 & 0 & 0 & 1.0049 & 0
\end{array}\right], \mathbf{B}=\left[\begin{array}{cc}
-0.9669 & 2.4680 \\
-77.6673 & 1.3287 \\
-3.0995 & -14.1149 \\
0 & 0 \\
0 & 0
\end{array}\right], \mathbf{C}=\left[\begin{array}{ccccc}
0.05 & 0 & 0 & 0 & 0 \\
0 & 1 & 0 & 0 & 0 \\
0 & 0 & 1 & 0 & 0 \\
0 & 0 & 0 & 1 & 0 \\
0 & 0 & 0 & 0 & 1
\end{array}\right] .
$$

It should be noted that matrix $\mathbf{D}$ is zero matrix for both longitudinal and lateral motions.

\section{ROBUST STRUCTURAL SYNTHESIS}

$H_{\infty}$-synthesis is a powerful instrument for design of the feedback control systems based on determination

of the bounded frequency responses as functions of the singular numbers. There is an approach for robust systems design, when the sufficient condition of the robust stability is formulated in the form of norms, bounded by the weighting transfer functions. This approach is accepted in such automated 
computer-aided facilities for the robust systems optimal design as the Robust Control Toolbox [12].

The synthesized system consists of the plant and controller described by the matrix transfer functions $\mathbf{G}(s), \mathbf{K}(s)$ respectively. These transfer functions must be fractionally-rational and proper. The generalized control object represents a system with two inputs and two outputs. The vector $\mathbf{w}$ represents the external output, which, in the general case, consists of disturbances, measurement noise and command signals. The input vector $\mathbf{u}$ represents the control signals. The output vector $\mathbf{z}$ determines the quality of the control processes. For example, it can be characterized by the command signal tracking error, which must be equal to zero in the ideal case. The output vector $\mathbf{y}$ represents the vector of the observed signals, which are used for feedback organization. The transfer function from input $\mathbf{w}$ to output $\mathbf{z}$ is denoted $\mathbf{W}_{w}^{z}$. Respectively, the main task of the $H_{\infty}$ - synthesis is the choice of such a controller $\mathbf{K}(s)$, which can minimize the $\left\|\mathbf{W}_{w}^{z}\right\|_{\infty}$ norm.

Implementation of the $H_{\infty}$-synthesis problem is based on solutions of the Riccati equations. For this it is necessary to satisfy the following conditions [12].

1) The pair of the matrices $\mathbf{A}, \mathbf{B}_{1}$ must be stabilizable and the pair of the matrices $\mathbf{A}, \mathbf{C}_{1}$ must be detectable.

2) The pair of the matrices $\mathbf{A}, \mathbf{B}_{2}$ must be stabilizable and the pair of the matrices $\mathbf{A}, \mathbf{C}_{2}$ must be detectable.

3) The following equality must take place $\mathbf{D}_{12}^{\mathrm{T}}\left[\begin{array}{ll}\mathbf{C}_{1} & \mathbf{D}_{12}\end{array}\right]=\left[\begin{array}{ll}\mathbf{0} & \mathbf{I}\end{array}\right]$.

4) The following expression must be true $\left[\begin{array}{c}\mathbf{B}_{1} \\ \mathbf{D}_{21}\end{array}\right] \mathbf{D}_{21}^{\mathrm{T}}=\left[\begin{array}{l}\mathbf{0} \\ \mathbf{I}\end{array}\right]$.

The conditions 1 and 2 guarantee the absence of imaginary eigenvalues of the Hamilton matrices, which correspond to the Riccati equations. The condition [13] means orthogonality of the signals $\mathbf{C}_{1} \mathbf{x}(t)$ and $\mathbf{D}_{12} \mathbf{u}(t)$. For the $H_{2}$-problem this condition means that the weighting control matrix in the norm of the vector $\mathbf{z}(t)=\mathbf{C}_{1} \mathbf{x}(t)+\mathbf{D}_{12} \mathbf{u}(t)$ is unitary and the components $\mathbf{z}(t)$ of the state vector $\mathbf{x}(t)$ and control vector $\mathbf{u}(t)$ do not influence on this norm. The condition 4 shows the orthogonality of the signals $\mathbf{B}_{1} \mathbf{w}(t)$ and $\mathbf{D}_{21} \mathbf{w}(t)$. So, the conditions
3, 4 are usual for the $H_{2}$-problem and spread on the case of the $H_{\infty}$-optimization [13].

It should be noted that in such statements of problems the plant is believed to be the set of some devices and units. This set of devices and units consists of the plant, motor, measuring system and some additional units.

There are the different statements of the tasks, which can be solved by the method of mixed sensitivity. One of these problems can be described by the generalized system and the optimization criterion in the following form [12]

$$
J(\mathbf{G}, \mathbf{K})=\left\|\left[\begin{array}{c}
\mathbf{W}_{1}(\mathbf{I}+\mathbf{G K})^{-1} \\
\mathbf{W}_{2} \mathbf{K}(\mathbf{I}+\mathbf{G K})^{-1} \\
\mathbf{W}_{3} \mathbf{G K}(\mathbf{I}+\mathbf{G K})^{-1}
\end{array}\right]\right\|_{\infty},
$$

here $\mathbf{W}_{1}, \mathbf{W}_{2}, \mathbf{W}_{3}$ are weighting transfer functions of the sensitivity functions [12].

$$
\mathbf{K}_{\text {опт }}=\arg \inf _{\mathbf{K}_{\text {опт }} \in \mathbf{K}_{\text {доп }}} J(\mathbf{G}, \mathbf{K}) .
$$

In the problem (15) the necessity to limit an error of the command signal tracking, the control signal and the output signal respectively are taking into account. The structural chart, which explains the statement of this problem, is represented in Fig. 5.

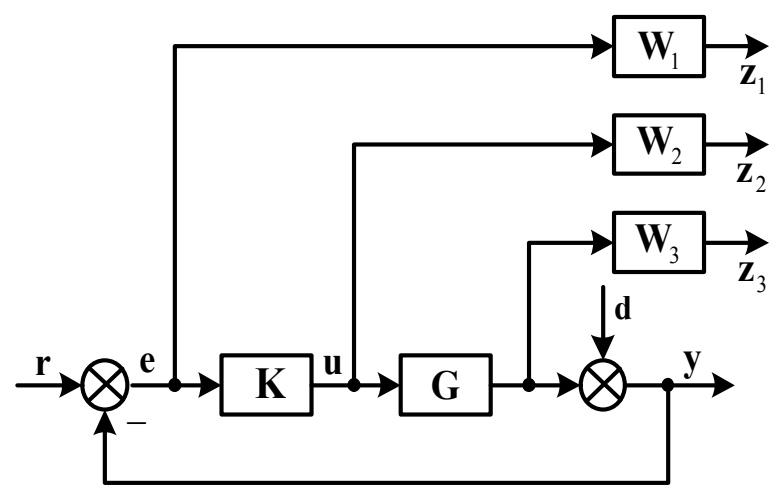

Fig.5. The structural chart for the method of mixed sensitivity with bounding of the error of the command signal tracking, the control signal and the output signal

The singular numbers of the closed transfer matrix functions from the command signal $\mathbf{r}$ to the signals of an error, input signals and output signal $\mathbf{e}, \mathbf{u}, \mathbf{y}$ [12] can be used for the quantitive estimation of the stability margins and frequency responses of the system.

Results of the synthesized system with the robust controller are represented in Figs 6 and 7.

Simulation results prove robust stability of the system in conditions of parametrical disturbances. 

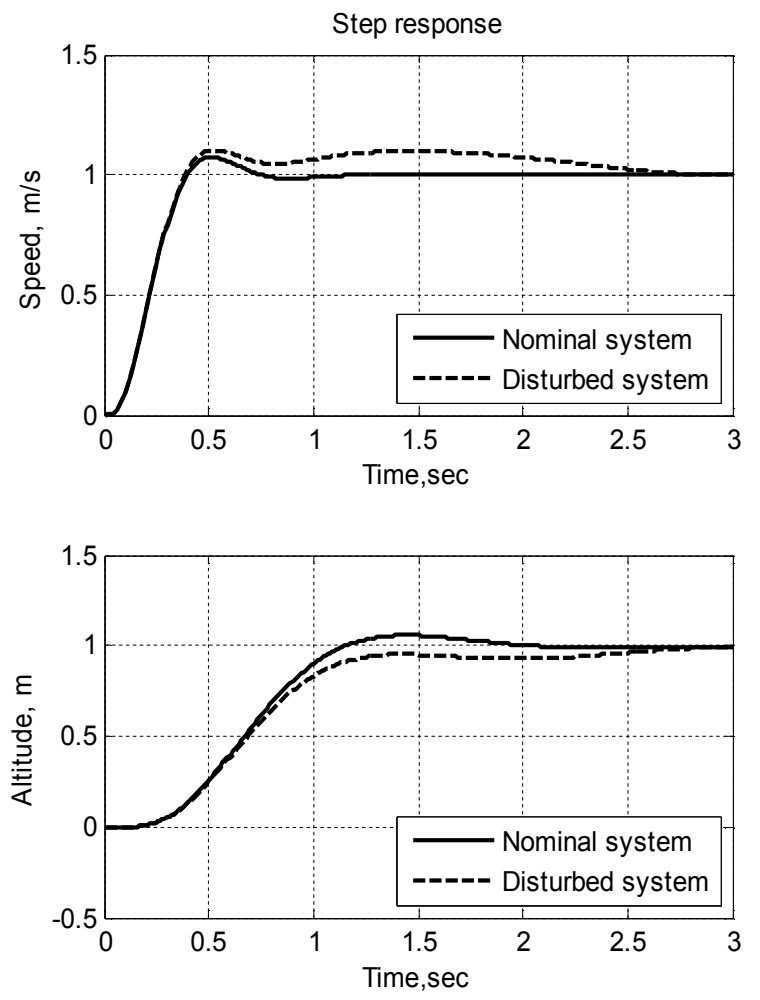

Fig. 6. Results of robust controller synthesis of the system for the longitudinal motion and step response
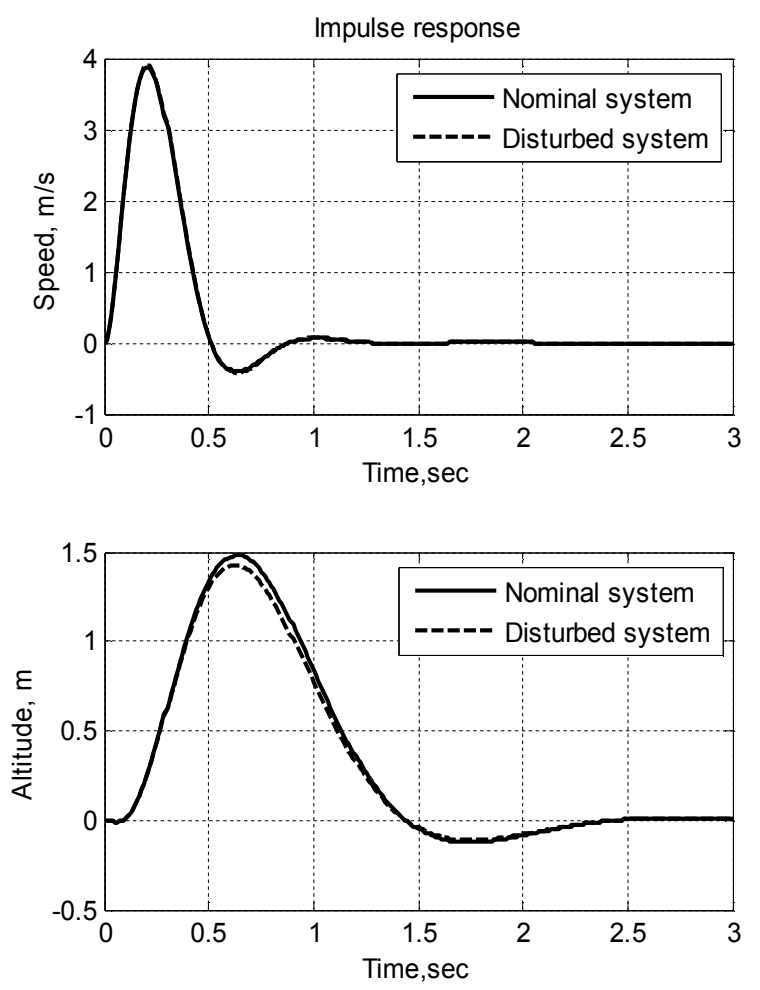

Fig. 7. Results of robust controller synthesis of the system for the lonitudinal motion and impulse response

\section{CONCLUSIONS}

The aggregation algorithm for determination of navigation information entering from the redundant measuring instrument was obtained.

The mathematical model of UAV longitudinal and lateral motions taking into consideration redundant measuring instrument based on inertial sensors has been done.

The robust control system based on the robust structural synthesis, namely, $H_{\infty}$ synthesis, was carried.

Combination of navigation information redundancy and robust controller provides improvement of a system's functioning in difficult condition of UAV real operation.

\section{REFERENCES}

[1] J. Cheng, J. Dong, R. Landry, and D. A. Chen, "Novel optimal configuration form redundant MEMS inertial sensors based on the orthogonal rotation method," Sensors, vol. 14(8), pp. 13661-13678, 2014.

[2] J. O. Nilsson, I. Skog, and P. Handel, An open-source multi inertial measurement unit (MIMU) platform. Inertial Sensors and Systems.

[3] O. A. Sushchenko, Y. N. Bezkorovainyi, and N. D. Novytska, "Nonorthogonal redundant configurations of inertial sensors," IEEE 4th International Conference Actual Problems of Unmanned Aerial Vehicles Developments (APUAVD), 2017.

[4] A. D. Epifanov, Redundant Systems of Aircraft Control. Moscow: Mashinostroenie, 1978, 178 p. (in Russian)

[5] O. A. Sushchenko, Y. N. Bezkorovainyi, and N. D. Novytska, "Theoretical and Experimental Assessments of Accuracy of Nonorthogonal MEMS Sensor Aarrays," EasternEuropean Journal of Enterprise Technologies, no. 3, pp. 78-87. Год???

[6] G. J. Holland, P. J. Webster, J. A. Curry and et al., The aerosonde robotic aircraft: a new paradigm for environmental observations, Bulletin of the American meteorological society, vol. 82, no. 5, 2001, pp. 889-901.

[7] D. McLean, Automatic Flight Control Systems, Prentice Hall, Inc., 1990, 593 p.

[8] J. C. Jeromel, P. L. Peres, and S. R. Souza, "Convex Analysis of Output Feedback Control Problems: Robust Stability and Performance," IEEE Trans, on Automatic Control. vol. 41, no. 7, Jul. 1996, pp. 903-1003.

[9] AeroSim - Aerospace Technology. Mode of direct access: AeroSimwww.aerospacetechnology.com/contractors/training/aerosim/

[10]A. A. Tunik, J. C. Kim, and C. S. Yoo, "The Parameter Optimization of Aircraft's Control Law from the Viewpoint of Some Airworthiness Requirements," Proceedings of the 12th Korea Automatic Control Conf. "97 KACC”. ICASE Publ. Seoul, 1997, pp. 1651-1654. 
[11]Brian L. Stevens and Frank F., Lewis, Aircraft Control and Simulation, [2nd ed.]. John Wiley \& Sons Inc., 2003, 665 p.

[12]S. Skogestad and I. Postlethwaite, Multivariable Feedback Control, New York: Jonh Wiley, 1997, $559 \mathrm{p}$.

Sushchenko Olha. Doctor of Engineering Science. Professor.

Aerospace Control Systems Department, Education \& Research Institute of Air Navigation, Electronics and Telecommunications, National Aviation University, Kyiv, Ukraine.

Education: Kyiv Polytechnic Institute, Kyiv, Ukraine, (1980).

Research interests: systems for stabilization of information-measuring devices operated at vehicles of the wide class.

Publications: 250.

E-mail: sushoa@ukr.net

Novytska Nataliia. Master. Assistant.

Aerospace Control Systems Department, Education \& Research Institute of Air Navigation, Electronics and Telecommunications, National Aviation University,

Kyiv, Ukraine.

Education: National Aviation University, (2008).

Research interest: control systems and processes.

Publications: 15.

E-mail: n-m@ukr.net

Bezkorovainyi Yurii. Candidate of Science (Engineering). Associate Professor.

Aerospace Control Systems Department, Education \& Research Institute of Air Navigation, Electronics and Telecommunications, National Aviation University,

Kyiv, Ukraine.

Education: National Aviation University, (2002).

Research interest: identification and control of complex systems.

Publications: 30.

E-mail: yurii.bezkor@gmail.com

Golitsyn Volodimir. Master.

Education: Education \& Research Institute of Air Navigation, Electronics and Telecommunications, National Aviation University, (2017).

Research interest: control systems and processes.

Publications: 3.

E-mail: vova.gol@ukr.net

О. А. Сущенко, Н. Д. Новицька, Ю. М. Безкоровайний, В. О. Голіцин. Робастна система управління БПЛА $з$ надмірним вимірювачем

У статті розглянуто синтез робастної системи, призначеної для експлуатації на БПЛА. Особливістю системи $є$ використання неортогонального вимірювача. Синтез регулятора було виконано на основі робастного структурного синтезу. Такий підхід засновано на створенні математичної моделі об'єкта управління. Тому було отримано моделі поздовжнього та бічного руху літального апарата. В цих моделях враховано неортогональну вимірювальну систему, що включає швидкісні гіроскопи, засновані на технологіях мікроелектромеханічних систем. Матриці стану, управління та спостереження було отримано за допомогою технології Аеrosim. Представлено результати моделювання синтезованої системи. Отримані результати можуть бути корисними для рухомих об'єктів широкого класу.

Ключові слова: система управління; неортогональна конфігурація; швидкісний гіроскоп; надмірність; робастний регулятор.

Сущенко Ольга Андріївна. Доктор технічних наук. Професор.

Кафедра систем аерокосмічних систем управління, Навчально-науковий інститут аеронавігації, електроніки та телекомунікацій, Національний авіаційний університет, Київ, Україна.

Освіта: Київський політехнічний інститут, Київ, Україна (1980).

Напрям наукової діяльності: системи стабілізації інформаційно-вимірювальних пристроїв, експлуатованих на рухомих об'єктах широкого класу.

Кількість публікацій: 250.

E-mail: sushoa@ukr.net

Новицька Наталія Дмитрівна. Магістр. Асистент.

Кафедра аерокосмічних систем управління, Навчально-науковий інститут аеронавігації, електроніки та телекомунікацій, Національний авіаційний університет, Київ, Україна.

Освіта: Національний авіаційний університет, (2008). 
Напрям наукової діяльності: системи та процеси управління.

Кількість публікацій: 15.

E-mail: n-m@ukr.net

Безкоровайний Юрій Миколайович. Кандидат технічних наук. Доцент.

Кафедра систем аерокосмічних систем управління, Навчально-науковий інститут аеронавігації, електроніки та телекомунікацій, Національний авіаційний університет, Київ, Україна.

Освіта: Національний авіаційний університет, (2002).

Напрям наукової діяльності: ідентифікація та управління складними системами.

Кількість публікацій: 30.

E-mail: yurii.bezkor@gmail.com

Голіцин Володимир Олександрович. Магістр.

Навчально-науковий інститут аеронавігації, електроніки та телекомунікацій, Національний авіаційний університет, Київ, Україна.

Освіта: Національний авіаційний університет, (2008).

Напрям наукової діяльності: системи та процеси управління.

Кількість публікацій: 3.

E-mail: vova.gol@ukr.net

О. А. Сущенко, Н. Д. Новицкая, Ю. М. Безкоровайный, В. А. Голицин. Робастная система управления БПЛА с избыточным измерителем

В статье рассмотрен синтез робастнойї системы, предназначенной для эксплуатации на БПЛА. Особенностью системы является использование неортогонального измерителя. Синтез регулятора был выполнен на основе робастного структурного синтеза. Такой подход основан на создании математической модели объекта управления. Поэтому были получены модели продольного и бокового движения летательного аппарата. В этих моделях учтена неортогональная измерительная система, которая включает скоростные гироскопы, основанные на технологиях микроэлектромеханических систем. Матрицы состояния, управления и наблюдения были получены при помощи технологии Aerosim. Представлены результаты моделирования синтезированной системы. Полученные результаты могут быть полезными для подвижных объектов широкого класса.

Ключевые слова: система управления; неортогональная конфигурация; скоростной гироскоп; избыточность; робастный регулятор.

Сущенко Ольга Андреевна. Доктор технических наук. Профессор.

Кафедра аэрокосмических систем управления, Учебно-научный институт аэронавигации, электроники и телекоммуникаций, Национальный авиационный университет, Киев, Украина.

Образование: Киевский политехнический институт, Киев, Украина, (1980).

Направление научной деятельности: системы стабилизации информационно-измерительных устройств, эксплуатируемых на подвижных объектах широкого класса.

Количество публикаций: 250.

E-mail: sushoa@ukr.net

Новицкая Наталия Дмитриевна. Магистр. Ассистент.

Кафедра систем аэрокосмических управления, Учебно-научный институт аэронавигации, электроники и телекомуникаций, Национальный авиационный университет, Киев, Украина.

Образование: Национальный авиационный университет, (2008).

Направление научной деятельности: системы и процессы управления.

Количество публикаций: 15.

E-mail: n-m@ukr.net

Безкоровайный Юрий Николаевич. Кандидат технических наук. Доцент.

Кафедра аэрокосмических систем управления, Учебно-научный институт аэронавигации, электроники и телекомуникаций, Национальный авиационный университет, Киев, Украина.

Образование: Национальный авиационный университет, (2002).

Направление научной деятельности: идентификация и управление сложными системами.

Количество публикаций: 30.

E-mail: yurii.bezkor@gmail.com

Голицин Владимир Александрович. Магистр.

Учебно-научный институт аэронавигации, электроники и телекоммуникаций, Национальный авиационный университет, Киев, Украина.

Образование: Национальный авиационный университет, (2008).

Направление научной деятельности: системы и процессы управления.

Количество публикаций: 3 .

E-mail: vova.gol@ukr.net 